\title{
Isolasi, karakterisasi, identifikasi, dan uji aktivitas antibakteri trigliserida biji mangga golek (Mangifera indica Linn)
}

\author{
Dian Fatmawati, Sutrisno*, Parlan \\ Universitas Negeri Malang, Jl. Semarang No. 5 Malang, Jawa Timur, Indonesia \\ *Penulis korespondensi, Surel: sutrisno.fmipa@um.ac.id
}

Paper received: Paper received: 01-02-2022; revised: 15-02-2022; accepted: 28-02-2022

\begin{abstract}
There has been research on the isolation, characterization, and identification of triglyceride seeds of mango golek (Mangiifera indica Linn) and its activity as antibacterial. Isolation process by maceration and soxhlet produces smooth component as triglycerides and was creamy white in colour. These golek mango seed kernel triglicerides has melting point $34-36{ }^{\circ} \mathrm{C}$, soluble in hexane, chloroform, acetone, and ethyl acetate, slightly soluble in methanol and insoluble in water, has a carbon-carbon double bond, acid number of 2.8, saponification number of 336.6, and iodine number of 25.4. The GCMS anlysis of methyl ester shown fatty acids contain in golek mango seed kernel triglicerides. The fatty acids are hexadecanoic (26.31\%), heptadecanoic (0.6\%), 9-octadecenoic (28.70\%), octadecanoic (25.86\%), 11-eicosenoic (1.74\%), eicosenoic (11.20\%), docosanoic (2.47\%), and tetracosanoic acid (2.39\%). Triglycerides of golek mango seed kernel has no potential as an antibacterial against Escherichia coli and Staphylococcus aureus.
\end{abstract}

Keywords: acetone extract; antibacterial; mango golek seed kernel; trygliserides

\begin{abstract}
Abstrak
Telah dilakukan penelitian mengenai isolasi, karakterisasi, dan identifikasi trigliserida biji mangga golek (Mangiifera indica Linn) serta aktivitasnya sebagai antibakteri. Isolasi dilakukan dengan maserasi dan soxhletasi menggunakan aseton diperoleh komponen padatan lunak berwarna putih kekuningan. Trigliserida biji mangga golek ini mempunyai titik lebur $34-36{ }^{\circ} \mathrm{C}$, larut dalam heksana, kloroform, aseton, dan etil asetat, sedikit larut dalam metanol, tidak larut dalam air, memiliki ikatan rangkap $C=C$, mempunyai bilangan asam 2,8, bilangan penyabunan 336,6 , dan bilangan iod 25,4 . Analisis secara GC-MS terhadap metil ester hasil trans-esterifikasi trigliserida biji mangga golek diperoleh informasi asam lemak penyusunnya. Asam-asam lemak tersebut adalah asam heksadekanoat $(26,31 \%)$, heptadekanoat $(0,60 \%)$, 9-oktadekenoat $(28,70 \%)$, oktadekanoat $(25,86 \%)$, 11-eikosenoat $(1,74 \%)$, eikosenoat $(11,20 \%)$, dokosanoat $(2,47 \%)$, dan tetrakosanoat $(2,39 \%)$. Trigliserida biji mangga golek tidak memiliki aktivitas antibakteri terhadap Escherichia coli dan Staphylococcus aureus.
\end{abstract}

Kata kunci: ekstrak aseton, antibakteri, biji mangga golek, trigliserida

\section{Pendahuluan}

Tanaman mangga merupakan salah satu jenis tanaman yang banyak ditemukan di Indonesia. Berdasarkan data Statistik Produksi Hortikultura tahun 2014 menunjukkan bahwa produksi mangga di Indonesia mencapai 2.431.330 ton dan berada di posisi kedua setelah pisang. Salah satu jenis yang banyak ditemukan di Indonesia adalah mangga golek. Pemanfaatan tanaman mangga di Indonesia masih sebatas bahan makanan atau minuman yang terbuat dari daging buahnya. Sedangkan bagian lain dari buah mangga seperti bijinya kurang dimanfaatkan. Biji merupakan produk akhir metabolisme tumbuhan. Biji berperan penting dalam proses regenerasi tumbuhan sebagai cikal bakal perkembangbiakannya yang sesuai dengan sifat induknya. Biji buah mangga diduga mengandung senyawa-senyawa unik yang dapat dieksplorasi manfaatnya. 
Beberapa penelitian tentang komponen dalam biji mangga telah banyak dilakukan. Abdalla et al (2007) melaporkan bahwa ekstrak metanol biji mangga mengandung komponen fenolik, minyak, zat tak tersabunkan, dan protein. Komponen fenolik dalam ekstrak metanol biji mangga menunjukkan adanya aktivitas antimikroba yang menghambat pertumbuhan Eschericia coli. Engels et al (2009) menyebutkan senyawa galotannin yang diperoleh dari ekstrak biji mangga mampu bertindak sebagai antibakteri terhadap Escherichia coli. Penelitian Kaur et al (2010) menunjukkan ekstrak metanol biji mangga mengandung senyawa-senyawa fitokimia seperti glikosida, saponin, flavonoid, tannin, dan alkaloid . Pada konsentrasi 100 $\mathrm{mg} / \mathrm{L}$ ekstrak metanol kernel biji mangga aktif sebagai antimikroba yang menghambat laju pertumbuhan Staphylococcus aureus dan Escherichia coli.

Menurut Agoramoorthy et al (2007) asam-asam lemak seperti asam palmitat, linoleat, oleat, dan stearat memiliki aktivitas antibakteri. Arogba (1997) dalam penelitiannya melaporkan bahwa di dalam fraksi minyak biji mangga verietas Ikanekpo yang diperoleh pada proses pengolahan tepung mengandung asam palmitat $10,5 \%$, asam stearat $27 \%$, asam oleat $48,3 \%$, dan asam linoleat $14,2 \%$. Kandungan asam-asam lemak dalam minyak biji mangga pada penelitian sebelumnya diduga terdapat pula dalam minyak biji mangga golek yang banyak ditemukan di Indonesia sehingga dapat diteliti aktivitas antibakterinya.

Ada dua metode uji aktivitas antibakteri yaitu dilusi dan difusi. Metode yang digunakan dalam penelitian ini adalah difusi. Prinsip dasar metode difusi adalah dengan cara menambahkan biakan bakteri uji dengan antibakteri pada masing-masing cawan petri yang berisi media agar dengan konsentrasi tertentu. Aktivitas antibakteri bahan uji terhadap bakteri ditentukan secara makroskopis setelah masa inkubasi berakhir, yaitu dengan melihat ada tidaknya zona bening. Kekuatan aktivitas antibakteri dapat ditentukan berdasarkan besarnya diameter zona hambat. Suatu zat tidak aktif antibakteri jika diameter zona hambatnya $<6 \mathrm{~mm}$, memiliki aktivitas sedang jika diameter zona hambatnya 6-11 $\mathrm{mm}$, dan memiliki aktivitas antibakteri yang kuat jika diameter zona hambatnya > $11 \mathrm{~mm}$ (Conner \& Beuchat, 1984).

Penelitian ini bertujuan untuk: (1) mengisolasi komponen ekstrak aseton biji mangga golek (Mangifera indica Linn); (2) mengkarakterisasi trigliserida biji mangga golek; (3) mengidentifikasi asam lemak penyusun trigliserida biji mangga golek; dan (4) menentukan aktivitas antibakteri ekstrak aseton dan trigliserida biji mangga golek. Pemilihan pelarut aseton yang bersifat semipolar diharapkan dapat menjebak senyawa-senyawa yang bersifat nonpolar sampai semipolar pada saat proses ekstraksi. Titik didih aseton yang rendah yaitu $56,2^{\circ} \mathrm{C}$ menyebabkan pelarut ini mudah menguap sehingga proses pemisahan pelarut menjadi lebih mudah. Selain itu, aseton juga memiliki toksisitas yang rendah dengan $\mathrm{LD}_{50} 3000 \mathrm{mg} / \mathrm{kg}$ mencit (MSDS, 2013).

\section{Metode}

\subsection{Alat dan Bahan}

2.1.1.Alat. Seperangkat alat gelas, neraca digital Durascale DAB 200 dengan ketelitian $0,001 \mathrm{~g}$, neraca analitik triple beam dengan ketelitian $0,1 \mathrm{~g}$, oven, seperangkat alat maserasi, seperangkat alat soxhlet, seperangkat alat rotary vacuum evaporator (rotavapor) merk Buchi Waterbath B-480, seperangkat alat Kromatografi Lapis Tipis (KLT), Fischer Scientific Melting Point Apparatus,corong pisah, seperangkat alat refluks, seperangkat alat titrasi, refraktometer Abbe, viskosimeter Ostwald, autoclave, Laminar Air Flow (LAF), jarum ose, vortex, spreader batang L, microtube, 
cawan petri, jangka sorong, seperangkat spektrofotometer FT-IR Shimadzu IRprestige 21 dan seperangkat alat Gas Chromatography-Mass Spectrometry/Kromatografi Gas-Spektrometri Massa (GC-MS) Shimadzu QP2010S.

2.1.2.Bahan. Buah mangga golek yang diperoleh dari Pasar Gadang Kota Malang, pelarut dari Merck berkualitas p.a yaitu heksana, kloroform, etil asetat, dan metanol. Pelarut aseton (destilat), akuades, larutan asam klorida $37 \%$, asam asetat glasial, asam sulfat $37 \%$, kalium iodida $10 \%$, karbon tetraklorida, indikator fenolftalein (pp), indikator amilum, brom, besi(III)klorida, kristal iod (teknis), padatan kalium hidroksida, natrium tiosulfat, magnesium sulfat anhidrat, pelat KLT dengan lapisan silika gel $60 \mathrm{~F}_{254}$ pada aluminium, nutrien agar (NA), nutrien cair (NC), ampisilin, larutan standar Mc Farland 0,5, bakteri biakan murni Staphylococcus aureus dan Escherichia coli (keduanya diperoleh di Laboratorium Mikrobiologi Jurusan Biologi FMIPA, Universitas Negeri Malang).

\subsection{Percobaan}

2.2.1.Preparasi sampel.Buah mangga golek dikupas kulit buahnya dan dipisahkan daging buah dengan bijinya. Biji yang diperoleh dikeringkan dalam oven pada suhu $45-50{ }^{\circ} \mathrm{C}$ selama 48 jam. Biji mangga golek dihaluskan sampai menjadi serbuk. Ekstraksi dilakukan melalui maserasi dan soxhletasi. Sebanyak 250,0 gram serbuk kering biji mangga golek dimaserasi dengan $400 \mathrm{~mL}$ aseton selama 24 jam. Dari proses maserasi diperoleh maserat 1 berupa campuran cairan berwarna kuning kecokelatan dan padatan putih yang mengendap di bawah serta residu 1. Maserat disimpan dan residu dimaserasi dengan $400 \mathrm{~mL}$ lagi selama 24 jam. Semua maserat yang diperoleh digabung menjadi satu disebut sebagai Fraksi $I$, sedangkan residu ditimbang. Maserat yang memiliki endapan padatan tersebut disaring sehingga diperoleh filtrat cairan berwarna coklat (Fraksi II) dan residu padatan berwarna putih kekuningan (Fraksi III).

Sebanyak 164,0 g residu 1 diekstraksi dengan metode soxhletasi menggunakan $700 \mathrm{~mL}$ aseton. Proses soxhletasi dilakukan terus menerus dan dihentikan sampai diperoleh warna pelarut identik dengan warna aseton sebelum digunakan soxhletasi. Ekstraksi dengan proses soxhletasi dihasilkan ekstrak soxhlet dan residu 2. Residu 2 disimpan dan tidak dianalisis lebih lanjut. Ekstrak hasil soxhlet dipisahkan berdasarkan wujudnya melalui filtrasi sehingga didapatkan komponen padat dan cair. Komponen dengan wujud padatan diuapkan pelarutnya di dalam desikator. Komponen yang berwujud cair diuapkan pelarutnya menggunakan alat rotary vacuum evaporator.

2.2.2.Karakterisasi dan identifikasi hasil isolasi. Karakterisasi dan identifikasi meliputi wujud, warna, kelarutan, uji penyabunan, uji ketidakjenuhan, titik lebur, bilangan asam, bilangan iod, bilangan penyabunan, dan interpretasi spektrum IR. Langkah-langkah karakterisasi hasil isolasi adalah sebagai berikut.

2.2.2.1.Wujud dan warna. Hasil isolasi dikarakterisasi wujud dan warna melalui pengamatan secara visual. 
2.2.2.2.Kelarutan. Sebanyak 0,010 g sampel dimasukkan ke dalam tabung reaksi kemudian ditambahkan 5 tetes sampai $2 \mathrm{~mL}$ pelarut (heksana, kloroform, etil asetat, aseton, metanol, dan air) kemudian dikocok dan diamati terbentuknya campuran yang homogen atau tidak larut.

2.2.2.3.Uji penyabunan. Sebanyak $0,010 \mathrm{~g}$ sampel yang dilarutkan dalam $1 \mathrm{~mL}$ heksana ditambahkan $1 \mathrm{~mL}$ larutan kalium hidroksida dalam metanol. Campuran tersebut dikocok hingga homogen. Uji positif adanya trigliserida ditandai dengan terbentuknya busa.

2.2.2.4.Uji ketidakjenuhan. Sebanyak 0,010 g sampel dilarutkan dalam $1 \mathrm{~mL}$ kloroform kemudian ditambahkan ke dalam 3 tetes brom dalam karbon tetraklorida. Uji positif adanya ikatan $\mathrm{C}=\mathrm{C}$ non aromatik ditandai dengan pudar atau hilangnya warna brom dalam karbon tetraklorida.

2.2.2.5.Titik lebur. Sedikit sampel diletakkan di atas kaca preparat kemudian diuji titik leburnya di atas hotplate pada alat Fischer Scientific Point Apparatus. Titik lebur sampel dicatat dari mulai lebur sampai melebur sempurna.

2.2.2.6.Bilangan asam. Sebanyak 0,500 g sampel dilarutkan dalam 2,5 mL heksana dimasukkan dalam Erlenmeyer $100 \mathrm{~mL}$ dan ditambahkan 3 tetes indikator fenolftalein. Campuran dikocok hingga homogen. Campuran yang telah homogen dititrasi dengan larutan kalium hidroksida 0,1 M hingga warna larutan menjadi merah muda yang konstan selama 20-30 detik.

2.2.2.7.Bilangan iod. Sebanyak 0,100 g sampel ditambah dengan $25 \mathrm{~mL}$ kloroform dan 10 mL larutan Hanus kemudian dimasukkan ke dalam Erlenmeyer 250 mL. Campuran dikocok hingga homogen dan didiamkan dalam ruang gelap. Campuran sesekali dikocok setiap 10 menit selama satu jam. Selanjutnya ke dalam campuran ditambahkan $10 \mathrm{ml}$ larutan kalium iodida $10 \%$ dan $100 \mathrm{~mL}$ akuades lalu campuran dititrasi dengan larutan natrium tiosulfat 0,1 M hingga larutan berubah warna menjadi kuning pucat. Ditambahkan 5 tetes indikator amilum sampai berwarna biru. Titrasi dilanjutkan hingga warna biru menghilang.

2.2.2.8. Bilangan penyabunan. Sebanyak $1,000 \mathrm{~g}$ sampel ditambah $5 \mathrm{~mL}$ heksana dan $25 \mathrm{~mL}$ larutan $\mathrm{KOH}$ 0,5M kemudian dimasukkan ke dalam labu alas datar $250 \mathrm{~mL}$. Campuran dikocok hingga homogen. Selanjutnya dimasukkan batu didih ke dalam campuran yang dihubungkan dengan pendingin tegak. Campuran dipanaskan hingga mendidih selama 30 menit lalu didinginkan pada temperatur ruang. Kemudian campuran ditambah 5 tetes indikator pp. Selanjutnya campuran dititrasi dengan larutan $\mathrm{HCl}$ 0,5 M hingga warna merah muda tepat hilang. Penentuan bilangan penyabunan juga dilakukan pada blanko dengan prosedur yang sama tanpa penambahan sampel.

2.2.2.9.Interpretasi spektrum IR. Sebanyak $1 \mathrm{mg}$ sampel dicampur dengan serbuk kering kalium bromida secara homogen kemudian digerus sampai kehalusan tertentu. Serbuk halus ini selanjutnya dibuat dalam bentuk 
lapisan tipis (pellet). Pellet ini dianalisis menggunakan spektrofotometer FT-IR pada bilangan gelombang $4000-400 \mathrm{~cm}^{-1}$.

2.2.3.trans-Esterifikasi trigliserida biji mangga golek menjadi metil ester. Sebanyak 3,003 g trigliserida dimasukkan labu leher tiga yang telah dipasang dengan refluks. Trigliserida dipanaskan hingga suhu $30^{\circ} \mathrm{C}$ lalu ditambahkan dengan 0,030 g kalium hiroksida dalam $0,7 \mathrm{ml}$ metanol p.a. selanjutnya campuran direfluks hingga perubahan konstan dan diamati perubahannya setiap 15 menit. Proses refluks kemudian dihentikan dan hasil refluks didinginkan pada suhu kamar. Selanjutnya hasil refluks dimasukkan corong pisah dan didiamkan selama 1 x 24 jam. Setelah terbentuk dua lapisan kemudian dipisahkan dan ditampung dalam wadah yang berbeda. Kedua lapisan kemudian diuji keasaman dengan kertas lakmus dan kelarutan dengan berbagai pelarut yaitu heksana, kloroform, dan air. Lapisan yang dapat larut dalam heksana dan kloroform namun tidak dapat larut dalam air diduga sebagai metil ester. Lapisan yang dapat larut dalam air namun tidak larut dalam heksana dan kloroform adalah gliserol. Metil ester yang diperoleh dimurnikan dengan cara dicuci menggunakan akuades hangat. Penambahan akuades hangat dilakukan hingga akuades sisa cucian tidak berwarna. Ditambahkan magnesium sulfat anhidrat ke dalam metil ester untuk menghilangkan sisa air.

2.2.4.Karakterisasi dan identifikasi metil ester hasil transformasi. Karakterisasi metil ester hasil transformasi meliputi analisis wujud dan warna, massa jenis, indeks bias, viskositas, uji kelarutan, penentuan bilangan asam, bilangan iod, bilangan penyabunan, dan diidentifikasi dengan FT-IR dan Gas ChromatographyMass Spectrofotometry (GC-MS) untuk mengetahui gugus fungsi, asam lemak penyusun, struktur, dan bobot molekul masing-masing komponen metil ester hasil transformasi berdasarkan pola fragmentasinya.

2.2.5.Uji aktivitas antibakteri. Uji aktivitas antibakteri dilakukan dengan metode difusi sumuran. Biakan murni (Staphylococcus aureus dan Escherichia coli) di dalam nutrien cair (NC) yang sudah distandardisasi dengan larutan Mc Farland 0,5 diinokulasikan ke dalam nutrien agar (NA) dengan cotton bud steril. Media NA yang berisi bakteri dilubangi dengan alat bor khusus sehingga membentuk lubang atau sumuran dengan diameter $6 \mathrm{~mm}$. Sebanyak $2 \mu \mathrm{L}$ sampel uji diinjeksikan ke dalam sumuran dalam media NA yang telah diinokulasik bakteri uji kemudian diinkubasi pada suhu $37^{\circ} \mathrm{C}$ selama 1 x 24 jam. Zona bening pada yang terbentuk di sekitar sumuran diukur menggunakan jangka sorong.

\section{Hasil dan Pembahasan}

Berdasarkan perlakuan preparasi sampel, diperoleh hasil sebagai berikut. Kadar air dalam biji mangga golek adalah 60,12 \% dan rendemen hasil ekstraksinya 18,2 \%. Hasil ekstraksi (Fraksi I) yang memiliki endapan padatan disaring sehingga diperoleh filtrat cairan berwarna coklat (Fraksi II) dan residu padatan berwarna putih kekuningan (Fraksi III). Seluruh hasil ekstraksi ditimbang, diperoleh Fraksi III sebanyak 8,6 g dan Fraksi II sebanyak 31,8 g dari 250 g serbuk biji mangga kering.

Analisis Fraksi III secara kromatografi lapis tipis dilakukan dengan menggunakan berbagai jenis eluen yaitu (1) kloroform, (2) kloroform: metanol 9:1, (3) kloroform : aseton 
9:1, dan (4) heksana : etil asetat 7:3. Hasil kromatogram menunjukkan bahwa dengan berbagai jenis eluen yang dicoba, Fraksi III hanya memberikan satu noda dengan nilai $R_{\mathrm{f}} 0,82$ untuk kromatogram eluen 1 dan 2, nilai $R_{\mathrm{f}} 0,91$ untuk kromatogram eluen 3, dan nilai $R_{\mathrm{f}} 0,93$ untuk kromatogram eluen 4. Dilihat dari banyaknya noda yang terdapat pada kromatogram KLT, dapat disimpulkan bahwa sekurang-kurangnya ada satu jenis komponen dalam Fraksi III.

Fraksi III dikarakterisasi berdasarkan sifat fisik dan kimianya. Fraksi ini berwujud padatan lunak berwarna putih kekuningan dan memiliki titik lebur $34-36^{\circ} \mathrm{C}$. Fraksi III larut dalam heksana, kloroform, etil asetat, aseton, sedikit larut dalam metanol dan tidak larut dalam air. Fraksi ini positif terhadap uji penyabunan dan ketidakjenuhan, memiliki bilangan asam 2,8, bilangan penyabunan 336,6, dan bilangan iod 25,4. Fraksi III diuji dengan larutan KOH 0,1 M menghasilkan busa. Hal ini mengindikasikan bahwa zat ini merupakan suatu trigliserida karena zat ini mengalami hidrolisis dan menghasilkan suatu garam kalium dari asam lemak

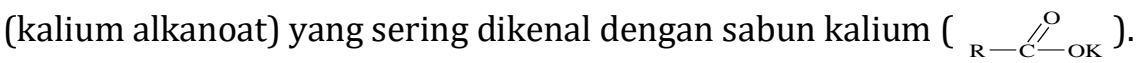

Berdasarkan data hasil karakterisasi Fraksi III merupakan trigliserida. Rantai karbon $\mathrm{R}_{1}$, $R_{2}$, dan $R_{3}$ mungkin sama atau berbeda dengan satu atau lebih kandungan ikatan rangkap karbon-karbon. Transformasi trigliserida biji mangga golek menjadi bentuk metil esternya dilakukan melalui reaksi trans-esterifikasi. Persamaan reaksinya adalah sebagai berikut:

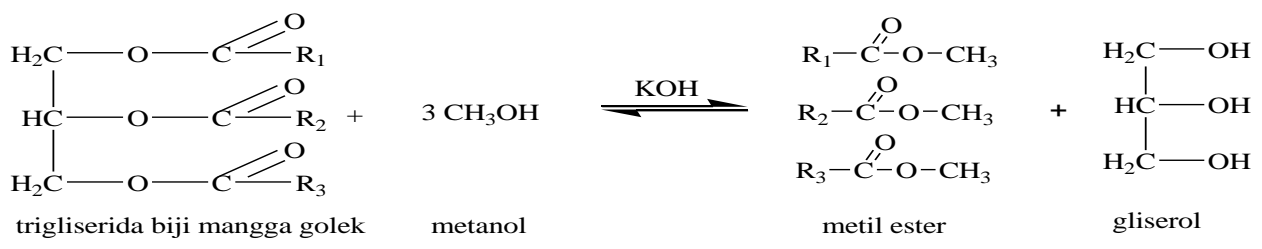

Rendemen metil ester hasil transformasi yaitu 85,8 \%. Rendemen ini diperoleh dari 3,003 g minyak biji mangga golek dan didapat metil ester sebanyak 2,574 g. Perbedaan karakteristik fisik dan kimia trigliserida biji mangga golek dengan metil esternya disajikan pada Tabel 1.

Metil ester hasil trans-esterifikasi memiliki bilangan asam yang lebih rendah dibandingkan trigliserida biji mangga golek karena jumlah asam lemak bebas yang terdapat dalam metil ester hasil transformasi lebih kecil dibandingkan dalam trigliseridanya. Selama reaksi trans-esterifikasi, asam-asam lemak bebas yang terdapat dalam trigliserida biji bereaksi dengan basa kalium hidroksida menjadi sabun atau garam kalium sehingga jumlahnya asam lemaknya berkurang.

Tabel 1. Perbandingan Karakteristik Trigliserida Biji Mangga Golek dan Metil Esternya.

\begin{tabular}{clll}
\hline No. & Karakteristik & $\begin{array}{l}\text { Trigliserida Biji } \\
\text { Mangga Golek }\end{array}$ & Metil Ester \\
\hline 1. & Wujud & Padatan lunak & Cair \\
2. & Warna & Putih kekuningan & Kuning \\
3. & Titik lebur & $34-36^{\circ} \mathrm{C}$ & - \\
4. & Massa jenis & - & $0,779 \mathrm{~g} / \mathrm{mL}$ \\
5. & Indeks bias & - & $1,451\left(25^{\circ} \mathrm{C}\right)$ \\
6. & Viskositas & - & $4,737 \mathrm{cSt}$ \\
7. & Bilangan asam & 2,8 & 1,12 \\
8. & Bilangan penyabunan & 336,6 & 168,32 \\
9. & Bilangan iod & 25,4 & 53,34 \\
\hline
\end{tabular}


Bilangan penyabunan trigliserida biji mangga adalah 336,6, sedangkan bilangan penyabunan metil esternya sebesar 168,32 . Secara teoritis, bilangan penyabunan trigliserida biji mangga golek dan metil esternya adalah sebesar 189,7. Perbedaan hasil eksperimen penentuan bilangan penyabunan ini dikarenakan pelarut heksana yang digunakan dalam trigliserida sukar larut dalam $\mathrm{KOH}$ metanolik sehingga campuran kurang homogen dan menyebabkan ketidaktepatan penentuan titik akhir titrasi.

Bilangan iod menunjukkan jumlah gram iod yang dapat diikat oleh 100 gram minyak atau lemak. Dengan mengetahui bilangan iod yang terdapat pada suatu minyak atau lemak, maka dapat diketahui derajat ketidakjenuhan asam yang terkandung dalam minyak tersebut. Bilangan iod trigliserida biji mangga golek adalah 25,4, sedangkan metil esternya sebesar 53,34. Data ini sesuai dengan teori yang menunjukkan jumlah partikel dalam $100 \mathrm{~g}$ trigliserida lebih kecil daripada jumlah partikel dalam $100 \mathrm{~g}$ metil esternya sehingga banyaknya iod yang diserap oleh metil ester lebih besar.

Identifikasi gugus fungsi trigliserida biji mangga golek dan metil esternya dilakukan dengan interpretasi spektrum IR. Spektrum IR trigliserida biji mangga golek ditunjukkan pada Gambar 1. Pita serapan tajam pada bilangan gelombang $3003,17 \mathrm{~cm}^{-1}$ mengindikasikan adanya vibrasi ulur $=\mathrm{C}-\mathrm{H}$. Terdapat pula pita serapan tajam dan kuat pada bilangan gelombang $2920,23 \mathrm{~cm}^{-1}$ dan $2850,79 \mathrm{~cm}^{-1}$ yang mengindikasikan adanya vibrasi ulur $\mathrm{C}-\mathrm{H}$ alkana pada gugus metilen. Pita serapan tajam dan kuat pada bilangan gelombang $1745,58 \mathrm{~cm}^{-1}$ mengindikasikan adanya gugus $\mathrm{C}=0$ ester. Gugus $\mathrm{C}=0$ ester tersebut didukung adanya pita serapan pada daerah sidik jari pada bilangan gelombang $1178,51 \mathrm{~cm}^{-1}$ yang merupakan vibrasi khas C-O ester.

\section{Gambar 1. Spektrum IR Trigliserida Biji Mangga Golek}

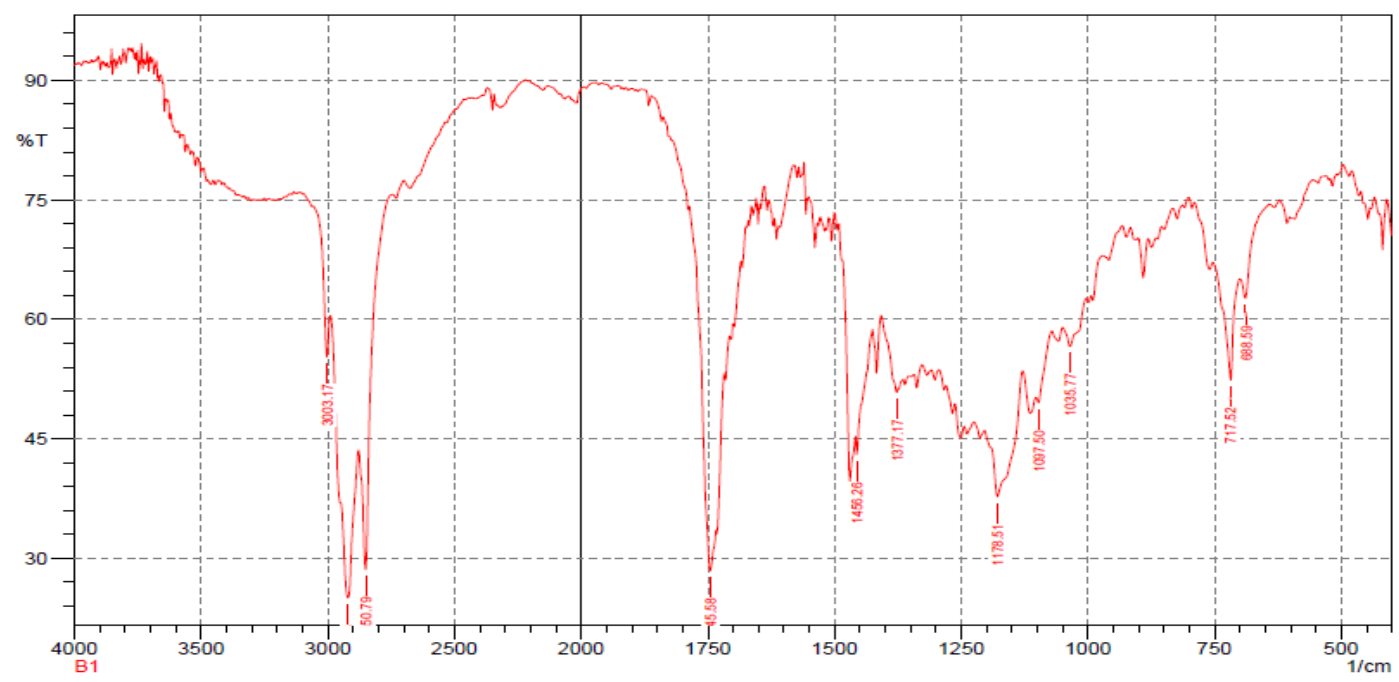


Gambar 2. Spektrum IR Metil Ester Hasil Transformasi

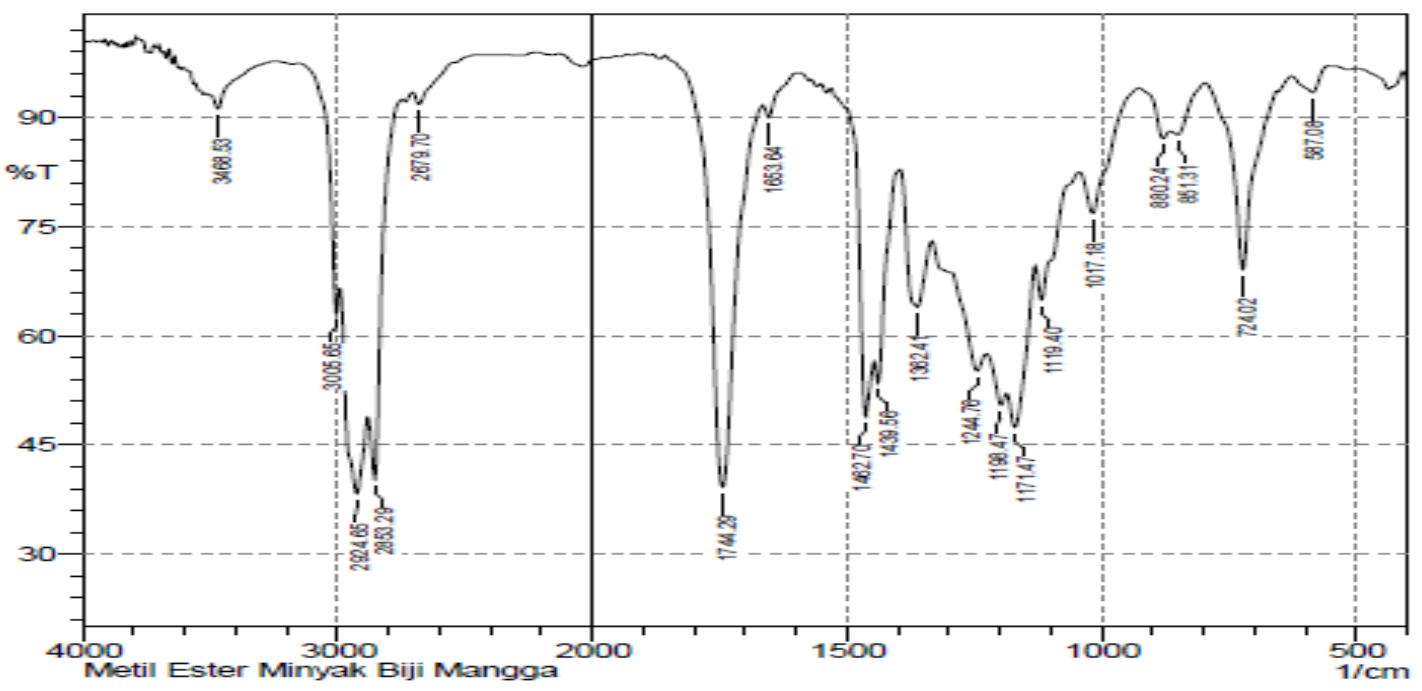

Berdasarkan spektrum IR metil ester yang ditunjukkan pada Gambar 2, bilangan gelombang yang muncul pada 3005,65 $\mathrm{cm}^{-1}$ mengindikasikan adanya gugus $=\mathrm{C}-\mathrm{H}$, data tersebut diperkuat dengan munculnya pita serapan lemah pada bilangan gelombang $2679,70 \mathrm{~cm}^{-1} \mathrm{dan}$ $1653,64 \mathrm{~cm}^{-1}$ yang mengindikasikan adanya vibrasi ulur $\mathrm{C}=\mathrm{C}$. Munculnya bilangan gelombang 2924,65 $\mathrm{cm}^{-1}$ mengindikasikan adanya vibrasi ulur $\mathrm{C}-\mathrm{H}$ gugus $\mathrm{CH}_{3}$, sedangkan bilangan gelombang $2853,29 \mathrm{~cm}^{-1}$ mengindikasikan adanya vibrasi ulur $\mathrm{C}-\mathrm{H}$ gugus $\mathrm{CH}_{2}$.

Munculnya bilangan gelombang $1744,29 \mathrm{~cm}^{-1}$ mengindikasikan adanya vibrasi ulur C=0 ester, hal ini didukung dengan munculnya bilangan gelombang pada daerah sidik jari 1244,76 $\mathrm{cm}^{-1}, 1198,47 \mathrm{~cm}^{-1}$, dan $1171,47 \mathrm{~cm}^{-1}$ yang mengindikasikan adanya vibrasi khas C-0 untuk gugus ester. Pita serapan untuk vibrasi ulur $\mathrm{C}=0$ pada metil ester lebih tajam dibandingkan dengan trigliseridanya. Hal ini dikarenakan di dalam trigliserida biji mangga golek masih banyak asam lemak bebas yang juga memiliki pita serapan vibrasi ulur $\mathrm{C}=0$ pada bilangan gelombang di sekitar pita serapan $\mathrm{C}=\mathrm{O}$ ester.

Metil ester diidentifikasi dengan GC-MS untuk mengetahui kandungan asam lemak penyusun dari trigliserida biji mangga golek. Identifikasi dilakukan berdasarkan puncakpuncak kromatogram yang muncul dan nilai m/z-nya. Puncak kromatogran metil ester ditunjukkan pada Gambar 3.

\section{Gambar 3. Puncak Kromatogram Metil Ester Hasil Transformasi}

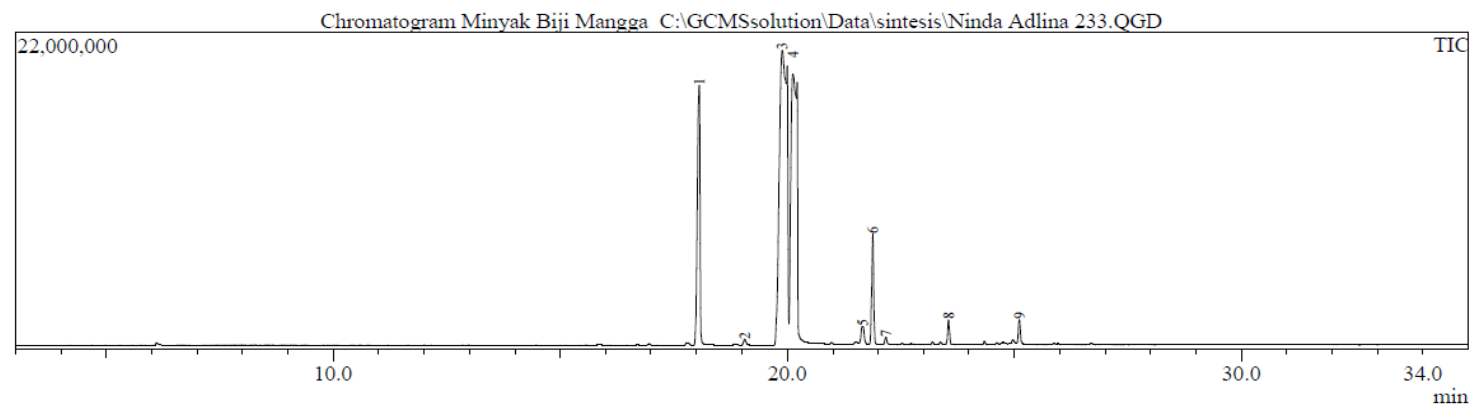


Berdasarkan hasil identifikasi menggunakan GC-MS, ada dua jenis asam lemak trigliserida biji mangga golek yaitu asam lemak tak jenuh dan jenuh. Asam lemak tak jenuhnya adalah asam 9-oktadekenoat (28,70 \%) dan (25,86 \%), asam 11-eikosenoat. Asam-asam lemak jenuhnya adalah asam heksadekanoat $(26,31 \%)$, heptadekanoat $(0,60 \%)$, oktadekanoat $(1,74$ $\%$ ), eikosanoat (11,20\%), dokosanoat (2,47\%), dan tetrakosanoat (2,39\%). Dilihat dari asam lemak penyusun trigliserida biji mangga golek, persentase asam lemak tak jenuhnya jauh lebih sedikit dibandingkan jenuhnya. Hal ini yang menyebabkan wujud dari trigliserida biji mangga golek berupa padatan lunak.

Hasil uji aktivitas antibakteri ekstrak aseton biji mangga golek dan trigliserida biji mangga golek ditunjukkan pada Gambar 4. Berdasarkan data hasil uji antibakteri, ekstrak aseton memiliki aktivitas antibakteri yang kuat dengan diameter zona hambat 17,85 mm terhadap Escherichia coli dan 15,76 terhadap Staphylococcus aureus. Trigliserida biji mangga golek tidak memiliki aktivitas antibakteri dengan diameter zona hambat 6,00 $\mathrm{mm}$ baik terhadap E. coli maupun S. aureus.

Gambar 4. Uji Aktivitas Antibakteri (a)Esktrak Aseton (Fraksi I) terhadap E. coli, (b)Fraksi I terhadap S. aureus, (c) Trigliserida Biji Mangga Golek (Fraksi III) terhadap E. coli, dan (d) Fraksi III terhadap $S$. aureus.

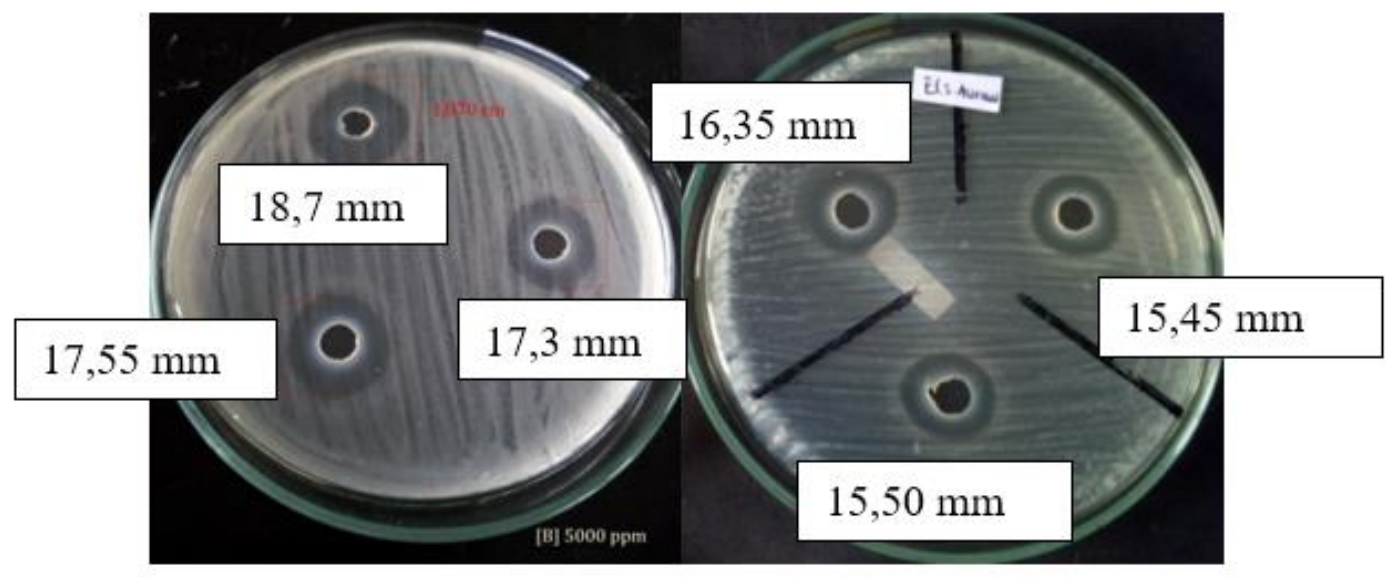

(a)

(b)

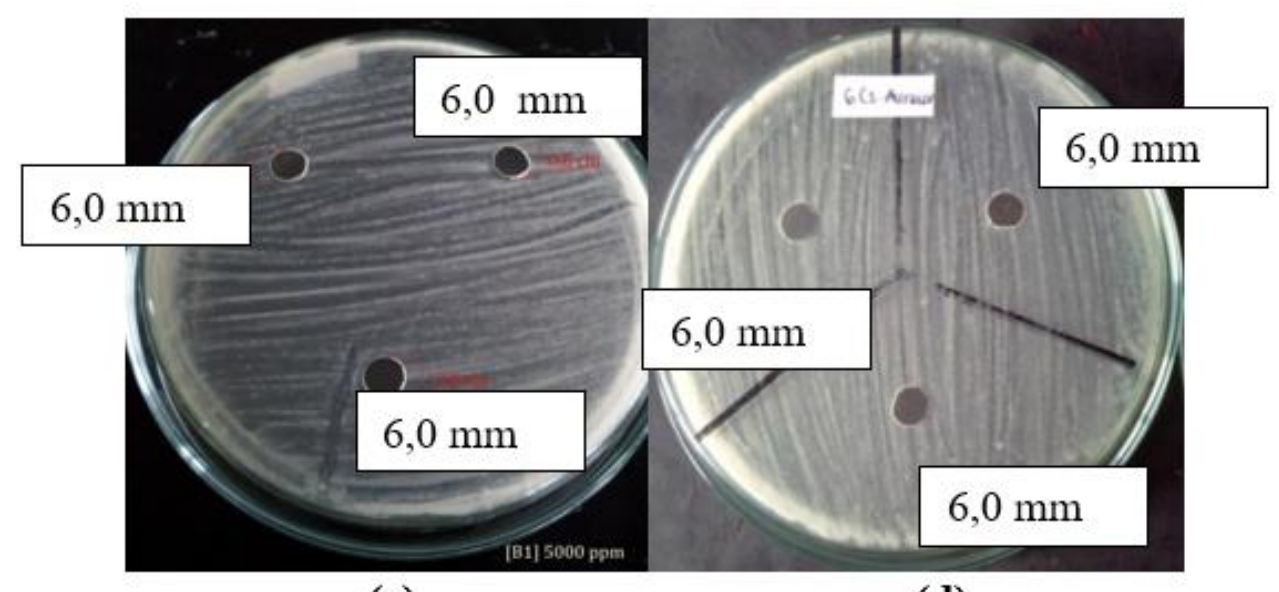

(c)

(d) 


\section{Simpulan}

Berdasarkan penelitian yang telah dilakukan diperoleh hasil sebagai berikut. Isolasi yang dilakukan secara maserasi dan soxhletasi dari biji mangga golek dengan pelarut aseton diperoleh zat padatan lunak berwarna putih kekuningan. Selanjutnya zat ini disebut sebagai trigliserida biji mangga golek dan tergolong sebagai lemak nabati. Trigliserida biji mangga golek memiliki titik lebur $34-36^{\circ} \mathrm{C}$, larut dalam heksana, kloroform, etil asetat, dan aseton. Zat ini memiliki bilangan asam 2,8, bilangan penyabunan 336,6 , dan bilangan iod 25,4.

trans-Esterifikasi trigliserida biji mangga golek dengan metanol dan katalis kalium hidroksdia menghasilkan metil ester berwujud cair, berwarna kuning yang memiliki massa jenis $0,779 \mathrm{~g} / \mathrm{mL}$, indeks bias $1,451\left(25^{\circ} \mathrm{C}\right)$, viskositas $4,737 \mathrm{cSt}$, bilangan asam 1,12 , bilangan penyabunan 168,32, dan bilangan iod 53,34. Analisis secara GC-MS terhadap metil ester hasil trans-esterifikasi diperoleh informasi asam lemak penyusunnya. Asam-asam lemak tersebut adalah asam heksadekanoat (26,31\%), asam heptadekanoat (0,60 \%), asam 9-oktadekenoat $(28,70 \%)$, asam oktadekanoat (25,86\%), asam 11-eikosenoat (1,74\%), asam eikosanoat $(11,20 \%)$, asam dokosanoat (2,47\%), dan asam tetrakosanoat (2,39\%). Trigliserida biji mangga golek ini tidak aktif sebagai antibakteri terhadap Staphylococcus aureus dan Escherichia coli.

\section{Daftar Rujukan}

Abdalla, A. E., Darwish, S. M., Ayad, E. H., \& El-Hamahmy, R. M. (2007). Egyptian mango by-product 1. Compositional quality of mango seed kernel. Food chemistry, 103(4), 1134-1140.

Abdalla, A. E., Darwish, S. M., Ayad, E. H., \& El-Hamahmy, R. M. (2007). Egyptian mango by-product 2: Antioxidant and antimicrobial activities of extract and oil from mango seed kernel. Food chemistry, 103(4), 11411152.

Agoramoorthy, G., Chandrasekaran, M., Venkatesalu, V., \& Hsu, M. J. (2007). Antibacterial and antifungal activities of fatty acid methyl esters of the blind-your-eye mangrove from India. Brazilian journal of Microbiology, 38, 739-742.

Arogba, S. S. (1997). Physical, chemical and functional properties of Nigerian mango (Mangifera indica) kernel and its processed flour. Journal of the Science of Food and Agriculture, 73(3), 321-328.

Conner, D. E., \& Beuchat, L. R. (1984). Effects of essential oils from plants on growth of food spoilage yeasts. Journal of food science, 49(2), 429-434.

Engels, C., KNOdler, M. A. T. T. H. I. A. S., Zhao, Y. Y., Carle, R., Gänzle, M. G., \& Schieber, A. (2009). Antimicrobial activity of gallotannins isolated from mango (Mangifera indica L.) kernels. Journal of agricultural and food chemistry, 57(17), 7712-7718.

Kabuki, T., Nakajima, H., Arai, M., Ueda, S., Kuwabara, Y., \& Dosako, S. I. (2000). Characterization of novel antimicrobial compounds from mango (Mangifera indica L.) kernel seeds. Food chemistry, 71(1), 61-66.

Kaur, J., Rathinam, X., Kasi, M., Leng, K. M., Ayyalu, R., Kathiresan, S., \& Subramaniam, S. (2010). Preliminary investigation on the antibacterial activity of mango (Mangifera indica L: Anacardiaceae) seed kernel. Asian Pacific Journal of Tropical Medicine, 3(9), 707-710.

MSDS. (2013). Acetone MSDS. (Online), retrieved 2017, 16 Mei from http://www.sciencelab.com/msds.php?msdsld=992-7062

Pusdatin (Pusat Data dan Sistem Informasi Pertanian). (2014). Outlook Komoditi Mangga. (Online) Retrieved 2017, 5 Juni from http://pusdatin.setjen.deptan.go.id/ 